Article

\title{
Strategic Planning Based on Sustainability for Urban Transportation: An Application to Decision-Making
}

\author{
Mustafa Hamurcu *(1) and Tamer Eren *(1) \\ Department of Industrial Engineering, Faculty of Engineering, Kırıkkale University, 71450 Kırıkkale, Turkey \\ * Correspondence: hamurcu.mustafa@kku.edu.tr (M.H.); tamereren@gmail.com (T.E.); \\ Tel.: +90-318-3574242 (T.E.)
}

Received: 19 March 2020; Accepted: 23 April 2020; Published: 28 April 2020

\begin{abstract}
Public transportation is one of the main goals of a developing city. This topic includes not only administrators, but also city residents and the environment, with economic, environmental, and social factors. This paper presents a multicriteria decision-making process for prioritizing alternative public transportation projects in Kırıkkale, considering the urban type of a developing city. It outlines three planned projects for improvement: "electric municipality bus", "light rail system", and the "modernization of existing vehicles and network optimization". In this study, we use the analytic hierarchy process and fuzzy technique for order preference by similarity to ideal situation (TOPSIS) application to prioritize transportation projects using economic, social, transportation, and environmental sub-criteria. The aim of this study is to select the most suitable project, based on sustainability, for more urban livability in Kirıkkale city. In the strategic decision-making process, the weights of each sustainability criteria have been determined using analytic hierarchy process (AHP). The fuzzy TOPSIS method has been applied for ranking the proposed alternative projects for Kırıkkale. Finally, the analytic decision process results are compared, and the electric municipality bus is selected as the best project alternative. The results of this study can not only offer a solution for current needs related to urban planning, but also ensure as a more transparent decision-making process for developing sustainability in developing cities in the near future.
\end{abstract}

Keywords: Kırıkkale; decision-making; multicriteria decision-making (MCDM); strategic planning; urban transportation

\section{Introduction}

Problems like traffic congestion, air and noise pollution, and increasing fuel consumption due to the use of private cars are among the major troubles for the quality of life in urban areas. These situations have been caused by many large impacts on the economy, natural ecosystem, and human health. In order to mitigate climate change potential, the reduction of greenhouse gas emissions from transportation is of vital importance for maintaining livable cities [1].

Urbanization is one of the dominant trends of environmental, economic, and social change in the developing world [2]. Transportation systems are also complex socio-technical systems and affect communities with their various dimensions [3]. Thus, the determination of public transportation systems is a strategic decision-making problem for urban areas and city managers $[4,5]$. Public transportation is one of the most critical components, especially in developing cities. The building of attractive public transport infrastructures and systems, bus network optimization, or the use of clean technological buses in developing cities will decrease the use of private vehicles and build a modern city.

The diversified needs of cities and developing technology and transportation types present new alternatives for urban transportation. In particular, sustainable transportation is one of the most 
important issues for developing cities and their city plans. When city plans are made, environmental, economic, technical, and social factors must be taken into consideration. Sustainability is one of the most important issues for transportation and life quality. Today, the concept of sustainability has some problems. Transport systems are largely motorized and dependent on non-renewable fossil fuels [6]. Emissions from vehicles contribute significantly to damage caused to the environment [7]. Besides, traffic congestion causes substantial economic losses in wasted time and fuel [8]. Minor innovations could contribute to creation solutions to these problems. For example, mass transportation could decrease the number of motorized vehicles. Alternative-fueled vehicles and cleaner technologies such as electric or rail systems are a good solution for traffic congestion and air quality. Thus, it will be possible to build more livable city centers. The aim of alternative transportation project selection is to provide maximum benefit for city traffic, social prosperity, clean environment, and developing urban transportation. It will provide livable urban environments and city centers. These investments need big resources, such as large budgets. So multicriteria decision-making methods are suitable tools for strategical decision-making in the transportation decision process.

Multicriteria decision-making (MCDM) methods in the evaluation process of transportation projects have gained importance, and have become widely used due to their simplicity in taking into account nonmarketable effects and qualitative criteria [9]. To be successful in the field of transportation planning, a combination of a scientific methodology and personal experience of the area is important. The complex multifactor nature of the problem can be handled by applying MCDM methods. In this paper, we use two-step methods consisting of an analytic hierarchy process (AHP) [10] and the technique for order performance by similarity to ideal solution (TOPSIS) [11]. In the first step, AHP is used for calculating the weights of the attributes or criteria as well as the overall weights of the candidates in each attribute. In order to encounter the uncertainty among alternatives, the TOPSIS method is combined with fuzzy sets theory [12]. Quite a lot of works using AHP and fuzzy TOPSIS approaches can be observed in the literature, but there is little research that combine these methods together for transportation.

Real-life applications increase in number for the decision-making process for transportation planning. Accordingly, the current paper proposes a hybrid approach that is able to deal with the importance of criteria in an uncertain environment and to select the alternative that is the closest to the possible ideal.

The contribution that our research makes to the literature is in proposing an MCDM approach, including an AHP-fuzzy TOPSIS methodology for strategic decision-making in developing provinces under fuzzy environment conditions and based on sustainability. In this research, the authors deal with existing transportation strategies of Kırıkkale and a neighbor, the capital Ankara, part of a developing province in Turkey. The context of developing cities presents wide-ranging differences from more developed settings. In particular, developing cities have some differences from developed cities regarding their rules, institutional arrangements, and governance practices [13].

Traffic-based problems in urban areas have become a major issue not only for big cities but also for small-scale towns such as Kırıkkale. The city of Kırıkkale is located in the Central Anatolia region of Turkey and has a population of about two hundred thousand. This situation has resulted in an uncontrolled population increase in the area, with serious urbanization problems including traffic-based subjects. In addition, there is a daily vehicle density through two major intercity highways which connect 43 provinces in all directions of the country. All these factors combined create a serious transportation problem in the area. The usage rate of special vehicles has also been increasing due to the insufficiencies in the current public transportation system. Thus, the current transportation network has not been presenting a sufficient transportation infrastructure.

Rapid population growth, poverty, income disparities, overcrowded urban cores, poorly designed road networks, spatial mismatches between housing and jobs, deteriorating environmental conditions, and economic losses from extreme traffic caused by congestion are among the more vexing challenges 
faced by developing cities. All these problems can be evaluated through the improved coordination of transportation and urban development [14].

Many cities have problems in the area of transportation arising from an inability to meet the rapid growth in travel demand. Many developing cities need urban public transportation, such as high-speed train and bus rapid transit investments. Many managers in developing cities also are working to reconfigure their urban public transport networks based on new projects with various implementations [15]. Given that a large share of future urban growth is projected for small-to-medium-sized cities, the strategic decision-making for transportation investments will be an important step. So, transportation planning needs to be elevated in importance in developing cities before it is too late.

In this study, the MCDM process includes evaluating the alternatives of urban transportation strategy under the fuzzy environment. This paper presents the evolution of a new approach for city and transportation planners that is flexible and practicable and based on sustainability. This research provides a useful guideline for the decision-making process for strategic transportation plans in many cities. Thus, this research makes a contribution to academic knowledge and public policy.

The paper is structured as follows: Section 1 gives information about urban transportation and an overview of the literature; Section 2 describes the MCDM and analytic methods used in this article; Section 3 presents an application for the selection process; Section 4 details the results and the corresponding discussion.

\section{Urban Transportation Planning}

Transportation planning and the assessment of the transportation system are important to ensure service quality and customer satisfaction, and to improve mobility in urban areas. However, the evaluation or planning of urban transportation systems is extremely complex and challenging. The performance of the transportation system is affected by various factors, such as transportation mode, demand, and location, etc. These effects can be both long term and short term [16]. Therefore, it is important to ensure that any infrastructure investment considers various evaluation factors, such as sustainability in the transportation evaluation or planning process.

The major purpose of urban transportation planning is to provide objective and useful inputs for decision-makers to provide, operate, and manage a functioning and efficient transportation system that meets the accessibility and mobility needs of various stakeholders. Transportation planning is widely used to identify, screen, and prioritize projects at multiple levels, where detailed analysis can be conducted to evaluate alternative projects at a municipal level based on different criteria [17].

The transportation planning process needs to be addressed by government agencies and society as a whole due to the major associated challenges and problems, such as the increasing demand for transport, the growing number of vehicles on the road, and the need to improve road infrastructure. In making acceptable public transportation systems all stakeholders play an important role and must ensure mobility in an urban area alongside other specifications, including providing high-quality services for users, being more attractive to users, and providing efficient use of urban spaces [18].

There are some approaches that can be used, such as simulation [19], lifecycle analysis [20], cost-benefit analysis [21], environment impact analysis [22], optimization [23], assessment indicator models [24], and fuzzy set theory [25]. All of the applications are important for transportation planning and evaluation. Among these applications, MCDM is widely used by many researchers in the planning of transportation systems. The complexity of the transportation issues and the inadequacies of conventional economic evaluation tools encouraged the development of MCDM methods and their hybrid applications [26]. Mobility management, public transport, infrastructure decisions, and the evaluation of technology are the main decision problem subjects for the application of MCDM in the transport sector [27]. MCDM methods are suitable techniques for the evaluation of urban public transportation problems and decision-making because of the effect of multiple actors, such as private and public sectors, and because they include environmental considerations. Decision-making in public 
transit is thus a very complicated task involving various economic, environmental, and socio-political issues [28].

Besides, recently, studies on urban public transport systems have begun to incorporate MCDM for problems, including various transportation subjects. These subjects and relevant research are shown in Table 1.

Table 1. Studies about transportation planning.

\begin{tabular}{|c|c|c|c|}
\hline Scope of the Study & Author/s (Year) & Method/s & Ref. \\
\hline \multirow{3}{*}{ Literature research } & Mahmoudi (2019) & LR & [28] \\
\hline & Stojčić et al. (2019) & LR & [29] \\
\hline & Perez et al. (2015) & LR & [30] \\
\hline \multirow{3}{*}{$\begin{array}{l}\text { Development of criteria } \\
\text { for evaluating projects }\end{array}$} & Mahmoudi et al. (2019) & BWM & [31] \\
\hline & Barfod and Salling (2015) & MCA & [32] \\
\hline & Jones et al. (2013) & MCDM & [17] \\
\hline \multirow{5}{*}{$\begin{array}{l}\text { Evaluation of transport } \\
\text { system infrastructure }\end{array}$} & Khayamim et al. (2020) & MP & [33] \\
\hline & Özcan et al. (2018) & MP & [34] \\
\hline & López Lambas et al. (2017) & GIS-TOPSIS & [35] \\
\hline & Wu et al. (2016) & PROMETHEE & [36] \\
\hline & Lee (2018) & AHP & {$[37]$} \\
\hline \multirow{3}{*}{$\begin{array}{l}\text { Policies in passenger } \\
\text { transport systems }\end{array}$} & Mohammadi et al. (2020) & MCA & [38] \\
\hline & Li et al. (2019) & AHP-VIKOR & [39] \\
\hline & Hickman et al. (2012) & MCA & [40] \\
\hline \multirow{3}{*}{ Public transport modes } & Seker and Aydin (2020) & IVIF-AHP-CODAS & [41] \\
\hline & Keyvan and Cats (2015) & TOPSIS & [42] \\
\hline & Yedla and Shrestha (2003) & AHP & [43] \\
\hline \multirow{5}{*}{ Selection of technologies } & Hamurcu and Eren (2020) & AHP-TOPSIS & [44] \\
\hline & Hamurcu and Eren (2020) & MOORA-TOPSIS & [45] \\
\hline & Salabun et al. (2019) & COMET & [46] \\
\hline & Dinç et al. (2018) & AHP/FAHP & [47] \\
\hline & Hamurcu and Eren (2017) & AHP-TOPSIS & [48] \\
\hline \multirow{7}{*}{$\begin{array}{l}\text { Analysis of service } \\
\text { performance }\end{array}$} & Kumar et al. (2020) & BWM-VIKOR & [49] \\
\hline & Cyril et al. (2019) & AHP-GP & [50] \\
\hline & Pedroso et al. (2018) & AHP & [51] \\
\hline & Aydin (2017) & Fuzzy sets-TOPSIS & [52] \\
\hline & Çelik et al. (2014) & VIKOR-fuzzy sets & [53] \\
\hline & d'Arcier et al. (2014) & No method & [54] \\
\hline & Mahmoud and Hine (2013) & AHP & [55] \\
\hline \multirow{7}{*}{$\begin{array}{l}\text { Selection of urban } \\
\text { transportation } \\
\text { alternatives fuel }\end{array}$} & Liang et al. (2019) & LGPPFAHP-FGMADA & [1] \\
\hline & Ulah et al. (2018) & AHP & [56] \\
\hline & Büyüközkan et al. (2018) & Fuzzy Choquet integral & [57] \\
\hline & Osorio-Tejada et al. (2017) & AHP & [58] \\
\hline & Oztaysi et al. (2017) & Fuzzy sets & [59] \\
\hline & Onat et al. (2016a) & TOPSIS-fuzzy set & [60] \\
\hline & Onat et al. (2016b) & MCDM & [61] \\
\hline \multirow{2}{*}{$\begin{array}{l}\text { Assessment of } \\
\text { alternative fuels }\end{array}$} & Mukherjee (2017) & FMCDM & [62] \\
\hline & Lanjewar et al. (2015) & Grap theory-AHP & [63] \\
\hline
\end{tabular}

(LR: literature review; BWM: best worst method; MCA:multi-criteria analysis; MP: mathematical programming; GIS: geographical information systems; IVIF: interval valued pythagorean fuzzy; CODAS: combinative distance-based assessment; MOORA: multi-objective optimization on the basis of ratio analysis; COMET; characteristic objects method; FAHP: fuzzy analytic hierarchy process; VIKOR: višekriterijumsko kompromisno rangiranje; LGPPFAHP: the linear goal programming priority based fuzzy analytic hierarchy process; FGMADA: fuzzy group multi-attribute decision analysis; FMCDM: fuzzy multi-criteria decision making)

Besides, there are some studies in the literature that have focused on sustainability-based development of urban transportation. For example, AHP was used by Shiau (2013) [64] for the assessment of sustainable transport strategies. Ruiz and Guevara (20209 used AHP to analysis 
strategies employed in the development of sustainable road maintenance policies in Colombia [65]. Jones et al. (2013) suggested a new framework for urban transportation. In their study, they made an evaluation of projects regarding based on sustainability criteria with AHP [17]. Gür et al. (2017) presented a multicriteria decision-making process and optimization model to the selection of a monorail route in Ankara, considering the urban types and city characteristics [66]. Luke and MacDonald (2006) deal with a similar problem to our work about transportation. They selected a public transport mode among light rail and bus-based options with a qualitative approach [67]. Hu and Guo (2014) developed an evaluation process comprised of three categories of influence factors, transportation characteristics, urban area characteristics, and public transportation policy. They examined the influence factors on public transit mode choice and established a new urban district public transit mode decision matrix [68]. In addition to these studies, there are also studies on issues such as a bus network of priority lanes [16], the site selection of car sharing station [69], the application for developing countries [70], system cost-based multicriteria analysis [71], prioritizing transport infrastructure projects [72], dynamic analysis of public bus transport [73], evaluating the transit service performance [74], decision analysis framework for intermodal transport [75], and multicriteria analysis of alternative-fueled buses [76-78].

It has been seen that MCDM methods have been used widely with transportation problems. This paper offers a new case study in Turkey in Kirıkkale. The paper proposes a model for evaluating transportation strategy, based on the combination of AHP and fuzzy TOPSIS. Important weights of evaluation criteria are calculated by using AHP. Then, after the TOPSIS method has been calculated with the help of linguistic variables, selection of the most appropriate strategy is realized.

\section{Multicriteria Decision-Making Methods}

In general, decision-making is the selective choice of an option from among other options. This decision-making process may be changed and developed according to the values and preferences of the decision-maker [79]. Varied MCDM methods have been applied in many areas. Analytic hierarchy process [80,81], analytic network process [82], PROMETHEE (Preference ranking organization method for enrichment and evaluations) [83], ELECTRE(Elimination et choix traduisant la realité) [84], VIKOR and TOPSIS [85], and best-worst method [86,87] are currently well-known techniques and widely used in the multiple criteria decision process. This study deals with also AHP and TOPSIS methods together with fuzzy sets.

\subsection{Literature Review on Combined AHP-TOPSIS}

In the academic literature, AHP and TOPSIS methods are considered in different ways, such as AHP TOPSIS [88-91], AHP-fuzzy TOPSIS [92,93], fuzzy AHP-TOPSIS [94,95], and fuzzy AHP-fuzzy TOPSIS [96-103].

The TOPSIS method is used widely for four reasons [104]: (1) the method logic is rational and understandable; (2) the computation processes are straightforward; (3) the decision process permits the pursuit of best alternatives for each criterion depicted in a simple mathematical form; (4) the importance weights are incorporated into the comparison procedures. Fuzzy TOPSIS provides an advantageous process to deal with incomplete and uncertain information due to the vagueness of the inherently subjective nature of human thinking. So, this fuzzy method gives a good result for the solution of the increasing complexity of the transportation decisions under a fuzzy environment.

The crisp values are one of the problematic processes in the evaluation process and in decision-making problems as some criteria are difficult to measure via the crisp value. Another issue is mathematical models that are based on crisp value. These methods cannot deal with decision-makers' ambiguities, uncertainties, and vagueness, which cannot be handled by crisp values [93]. The fuzzy set theory was proposed by Zadeh in 1965 and helps decision-makers to incorporate unquantifiable information and incomplete information into their decisions [105]. The advantage of this integration is that TOPSIS is characterized by simplicity. Further, TOPSIS has the ability to not change its process steps according to problem size. AHP is able to present an unstructured, complex problem in a reliable 
decision hierarchic structure that includes various levels (these levels are criteria, sub-criteria, and alternatives) to determine the best decision. This method has some advantages, such as the use of decision-makers' opinions for pairwise comparisons and to determine the importance weights of the criteria and alternatives. It is also able to be tested via a consistency ratio (CR) to validate the consistency of the pairwise comparisons. Thus, this paper aims to provide an AHP-fuzzy TOPSIS methodology useful to transportation planners in the selection of alternative transportation strategies.

\subsection{Analytic Hierarchy Process (AHP)}

The AHP method is useful in making the best decision using quantitative and qualitative aspects of a decision and in establishing priorities. Numerous studies have used the AHP method to prioritize selection criteria in various areas [106-112]. Bulleted AHP - which is based on three main processes: (1) the construction of a decision hierarchy, (2) priority setting, and (3) testing of consistency [81]—was developed by Saaty [113-115]. Thus, the application of AHP has become a popular research method in various fields for assessing, rating, and determining the importance of weightings for selection criteria. AHP is used to allocate weights and rate the selected assessment criteria for the alternatives. This method can distinguish the important criteria from the other criteria by assigning numerical weights representing the relative importance of each assessment criterion. This study adopted a five-stage AHP [95,116]:

Step 1. Problem definition and the objective of the decision-making problem.

Step 2. Building of the hierarchy model. The simple hierarchy model was structured with three levels: the top, the intermediate, and the lowest level.

Step 3. Pairwise comparison among the criteria and alternatives by using a 1-9 scale. The scale was used to rate the relative importance of the assessment themes, as shown in Table 2.

Table 2. Scale of Importance.

\begin{tabular}{cc}
\hline Importance for Pairwise Comparisons Score & Score \\
\hline Extreme importance & 9 \\
Very strong importance & 7 \\
Strong importance & 5 \\
Moderate importance & 3 \\
Equal importance & 1 \\
\hline
\end{tabular}

The nine-point scale showed the level of relative importance by the numbers 1, 3, 5, 7, and 9, which indicated equal, moderate, strong, very strong, and extreme levels of the theme's importance. The intermediate values were represented by $2,4,6$, and 8 .

Step 4. Consistency ratio (CR) testing was done for control in order to avoid inconsistencies in the judgmental matrix. The CR is calculated using the Equation (1) found in [114].

$$
C R=\frac{C I}{R I}
$$

where $\mathrm{CR}$ is the consistency ratio, $\mathrm{CI}$ is the consistency index, and $\mathrm{RI}$ is the random index. The $\mathrm{CI}$ is calculated using the Equation (2)

$$
C I=\frac{\lambda_{\max }-n}{n-1}
$$

where the approximation of the maximum is $\lambda_{\max }$ and $n$ is number of elements.

The acceptable consistency index has been settled by Saaty (1994) [116] at 0.10. If the consistency ratio is lower than 0.10 , then the weight results are valid. However, if the consistency ratio is larger than 0.10 , then the results are inconsistent and are thus discarded. 
Step 5. The weighting score was calculated for each of the options (alternatives or criteria). The relative weights are given by the right eigenvector $(\mathrm{w})$ corresponding to the largest eigenvalue $(\lambda \max )$, as;

$$
A w=\lambda_{\max } * w
$$

When vector $\mathrm{w}$ was normalized, the vector of the priorities of the assessment themes was generated with respect to the goal. The weighting coefficient could be easily calculated using the Super Decision or Expert Choice software, or Microsoft. Office Excel. The random index (RI) is given in Table 3.

Table 3. Random Index (RI).

\begin{tabular}{cccccc}
\hline Number of Criteria & $\mathbf{1}$ & $\mathbf{2}$ & $\mathbf{3}$ & $\mathbf{4}$ & $\mathbf{5}$ \\
\hline RI & 0 & 0 & 0.58 & 0.90 & 1.12 \\
\hline Number of criteria & 6 & 7 & 8 & 9 & 10 \\
RI & 1.24 & 1.32 & 1.41 & 1.45 & 1.49 \\
\hline
\end{tabular}

\subsection{Fuzzy Set Theory}

The fuzzy set theory that was first proposed by Zadeh [12] and has been applied to diverse fields. In theory, the value of an element is determined via the membership of the element within a fuzzy set, resulting in a value between $0-1$. Some basic definitions of fuzzy sets are as follows.

Definition 1. Let $X$ is a set (space), with generic element of $X$ denoted by $x$, that is $X=\{x\}$. Then a fuzzy set is defined as Equation (4)

$$
\mathrm{A}=\left\{\left\langle\mathrm{x}, \quad \mu_{\mathrm{A}}(\mathrm{x})\right\rangle \mid \mathrm{x} \in \mathrm{X}\right\}
$$

where $\mu_{A}: X \rightarrow[0,1]$ (the membership function of the set $\mathrm{A}$ )

$\mu_{A}(x) \epsilon[0,1]$ : the degree of membership of the element $x$ to the set $\mathrm{A}$.

Definition 2. Triangular fuzzy number is represented as triplet $\widetilde{A}=\left[\begin{array}{ll}a_{1} & a_{2}, a_{3}\end{array}\right]$, where $a_{1}, a_{2}, a_{3}$ are crisp numbers. The membership function of $\widetilde{A}$ is defined as in Equation (5).

$$
f_{\widetilde{A}}(x)=\left\{\begin{array}{cc}
0 & x<a \\
\frac{x-a_{1}}{a_{2}-a_{1}} & a_{1} \leq x<a_{2} \\
\frac{a_{3}-x}{a_{3}-a_{2}} & a_{2} \leq x<a_{3} \\
0 & x>a_{3}
\end{array} .\right.
$$

\subsection{Fuzzy TOPSIS Method}

The TOPSIS method is a solution that maximizes the benefit criteria and minimizes the cost criteria and was first developed by Hwang and Yoon in 1981 [117]. The negative ideal solution is a solution that maximizes the cost criter and minimizes the benefit criteria [118]. There have been lots of studies in the literature dealing with the use of TOPSIS for the solution of complex decision problems [119-122]. The TOPSIS method includes the following definitions [123]:

Definition 3. Let $\widetilde{A}=\left(\begin{array}{lll}a_{1}, & a_{2}, & a_{3}\end{array}\right), \widetilde{B}=\left(\begin{array}{lll}b_{1}, & b_{2}, & b_{3}\end{array}\right)$ be two fuzzy numbers, so their mathematical relations can be defined as Equations (6) and (7):

$$
\begin{aligned}
& \widetilde{A} \bigoplus \widetilde{B}=\left(\begin{array}{lll}
a_{1}, & a_{2}, & a_{3}
\end{array}\right) \bigoplus\left(\begin{array}{lll}
b_{1}, & b_{2}, & b_{3}
\end{array}\right)=\left(\begin{array}{lll}
a_{1}+b_{1}, & a_{2}+b_{2}, & a_{3}+b_{3}
\end{array}\right) ;
\end{aligned}
$$

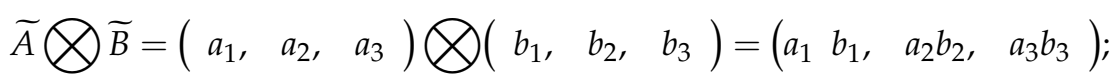


Definition 4. Let $\widetilde{A}=\left(\begin{array}{lll}a_{i 1}, & a_{i 2}, a_{i 3}\end{array}\right)$ be a triangular fuzzy number for $i \in I$. Then the normalized fuzzy number of each $\widetilde{A}_{i}$ is expressed as:

$\widetilde{R}=\left[r_{i j}\right]_{m x n^{\prime}} \mathrm{I}=1,2, \ldots, \mathrm{m} ; \mathrm{j}=1,2, \ldots, \mathrm{n}$, for benefit-type criteria, the normalization processing is expressed as Equation (8):

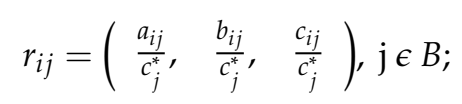

For cost-type criteria, the normalization processing is expressed as Equation (9) where B represents the sets of benefit criteria and $C$ the sets of cost criteria.

$$
\begin{gathered}
r_{i j}=\left(\begin{array}{ccc}
\frac{a_{j}^{-}}{c_{i j}^{*}}, \frac{a_{j}^{-}}{b_{j}^{*}}, & \frac{a_{j}^{-}}{a_{j}^{*}}
\end{array}\right), \mathrm{j} \in C ; \\
c_{j}^{*}=\max _{i} c_{i j}, \quad j \in B ; \\
a_{j}^{*}=\min _{i j} \quad j \in C ;
\end{gathered}
$$

Definition 5. The distance between two triangular fuzzy numbers $\widetilde{A}=\left(\begin{array}{ll}a_{i 1}, a_{i 2}, a_{i 3}\end{array}\right), \widetilde{B}=$ $\left(b_{1}, b_{2}, b_{3}\right)$ can be defined by the Euclidean distance with Equation (12).

$$
d(\widetilde{A}, \widetilde{B})=\sqrt{\frac{1}{3}\left[\left(a_{1}-b_{1}\right)^{2}+\left(a_{2}-b_{2}\right)^{2}+\left(a_{3}-b_{3}\right)^{2}\right]}
$$

Definition 6. The linguistic variable is used due to the fuzziness of human thought that results in decision-making. The linguistic variables for this study are shown in Table 4.

Table 4. Linguistic values and fuzzy numbers.

\begin{tabular}{cc}
\hline Linguistic Values & Fuzzy Numbers \\
\hline Very low (VL) & $(0.0,0.0,0.2)$ \\
Low (L) & $(0.0,0.2,0.4)$ \\
Medium (M) & $(0.2,0.4,0.6)$ \\
High (H) & $(0.4,0.6,0.8)$ \\
Very high (VH) & $(0.6,0.8,1.0)$ \\
Excellent(E) & $(0.8,1.0,1.0)$ \\
\hline
\end{tabular}

According to briefly summarized fuzzy theory above, fuzzy TOPSIS steps can be outlined as follows [92]:

Step 1. Choose the linguistic values for alternatives with respect to the criteria and using the following formula:

Linguistic values: $\widetilde{X_{i j}}, i=1,2, \ldots n, j=1,2, \ldots J$;

The fuzzy linguistic rating: $\widetilde{X_{i j}}\left(\widetilde{X_{i j}} \in[0,1]\right)$.

Step 2. Calculate the weighted normalized fuzzy-decision matrix.

The weighted normalized value can be calculated as follows.

$$
\begin{gathered}
\widetilde{V}=\left[\widetilde{V}_{i j}\right]_{n x j^{\prime}} i=1,2, \ldots, n, j=1,2, \ldots, J \\
\widetilde{V}_{i j}=\widetilde{X}_{i j} x W_{i}
\end{gathered}
$$

Step 3. Identify the positive-ideal $\left(\mathrm{A}^{*}\right)$ and negative-ideal $\left(A^{-}\right)$solutions $\left(\mathrm{I}^{\prime}\right.$ : benefit criteria, and $\mathrm{I}^{\prime \prime}$ : cost criteria) and the fuzzy positive-ideal solution FPIS, $\mathrm{A}^{*}$ : 


$$
\begin{aligned}
A^{*}=\left\{\begin{array}{rrrr}
\widetilde{V_{1}^{*}} & \widetilde{V_{2}^{*}} & \ldots & \widetilde{V_{i}^{*}}
\end{array}\right\} \\
A^{*}=\left\{\left(\max _{j} v_{i j} \mid i \in I^{\prime}\right), x \quad\left(\min _{j} v_{i j} \mid i \epsilon I^{\prime \prime}\right)\right\}
\end{aligned}
$$

$i=1,2, \ldots, n, j=1,2, \ldots, J$

The fuzzy negative-ideal solution (FNIS, $A^{-}$)

$$
\begin{aligned}
& A^{-}=\left\{\begin{array}{lll}
V_{1}^{-}, \widehat{V_{2}^{-}}, \ldots & \widetilde{V}_{i}^{-}
\end{array}\right\} \\
& A^{-}=\left\{\left(\min _{j} v_{i j} \mid i \epsilon I^{l}\right), x\left(\max _{j}|i j| i I^{\prime \prime}\right)\right\}
\end{aligned}
$$

$i=1,2, \ldots, n, j=1,2, \ldots, J$

Step 4. Calculate the distance of each alternative from $A^{*}$ and $A^{-}$using the following equations (Equations (17) and (18)):

$$
\begin{aligned}
& d_{j}^{*}=\sum_{j=1}^{n} d\left(\widetilde{V_{i j},} \quad \widetilde{V_{i}^{*}}\right) j=1,2, \ldots, J \\
& d_{j}^{-}=\sum_{j=1}^{n} d\left(\widetilde{V_{i j}}, \widetilde{V_{i}^{-}}\right) j=1,2, \ldots, J
\end{aligned}
$$

Step 5. Calculate the similarities to the ideal solution using Equation (19)

$$
C C_{j}=\frac{d_{j}^{-}}{d_{j}^{*}+d_{j}^{-}} j=1,2, \ldots J .
$$

\subsection{Research Methodology}

The proposed MCDM (AHP-based fuzzy TOPSIS) model for the strategy selection problem for urban transportation consisted of three basic stages: firstly, the determination of the criteria and alternatives to be used in the decision-making process; secondly, the AHP computations for the weights of criteria and the evaluation of alternatives with TOPSIS; and, finally, the determination of the best option. The research methodology is shown in Figure 1.

During the first stage, the alternatives and the evaluation criteria used in the evaluation process were determined and the decision hierarchy was formed with AHP. These transportation projects are planned by urban managers to improve urban transportation in the near future. Evaluation criteria are created from sustainability-based academic studies in the literature. Further, the creation process of the criteria set benefited from expert opinions

There are many factors that have effects on the urban transport project prioritization process, such as environmental pollutions, visual effect, land use, investment cost, acceptability, accessibility, travel time, and comfort, etc. Thus, the first step of the methodology was to select the project prioritization criteria that reflected the interests of the studied region. We determined the evaluation criteria via the literature and expert opinion. The evaluation criteria were decomposed into two-level hierarchy structures as the main criteria and sub-criteria. The higher level had four general sustainability categories: environment, economic, social, and transportation. These main criteria had 14 sub-criteria.

The model structure of AHP has a three-level hierarchy so that the objective is in the first level, criteria are in the second level, and the alternative strategies are in the third level. The created decision hierarchy was approved by the expert team in the last step. In this study, considering the professional fields of the experts and their understanding of the transportation status of Kırıkkale City, two experts from the city municipality and four experts from the academic sector were selected (six in total) to apply to their opinions. After the approval of the decision hierarchy, the criteria used in the decision-making process were assigned weights using the classic AHP steps. In this phase, pairwise comparison matrices 
were created by using Saaty's 1-9 scale. Expert opinions were very important in determining the criteria weights at this stage. All pairwise comparisons, according to expert opinion and numeric calculates, were controlled with a consistency test in the final step of the AHP.

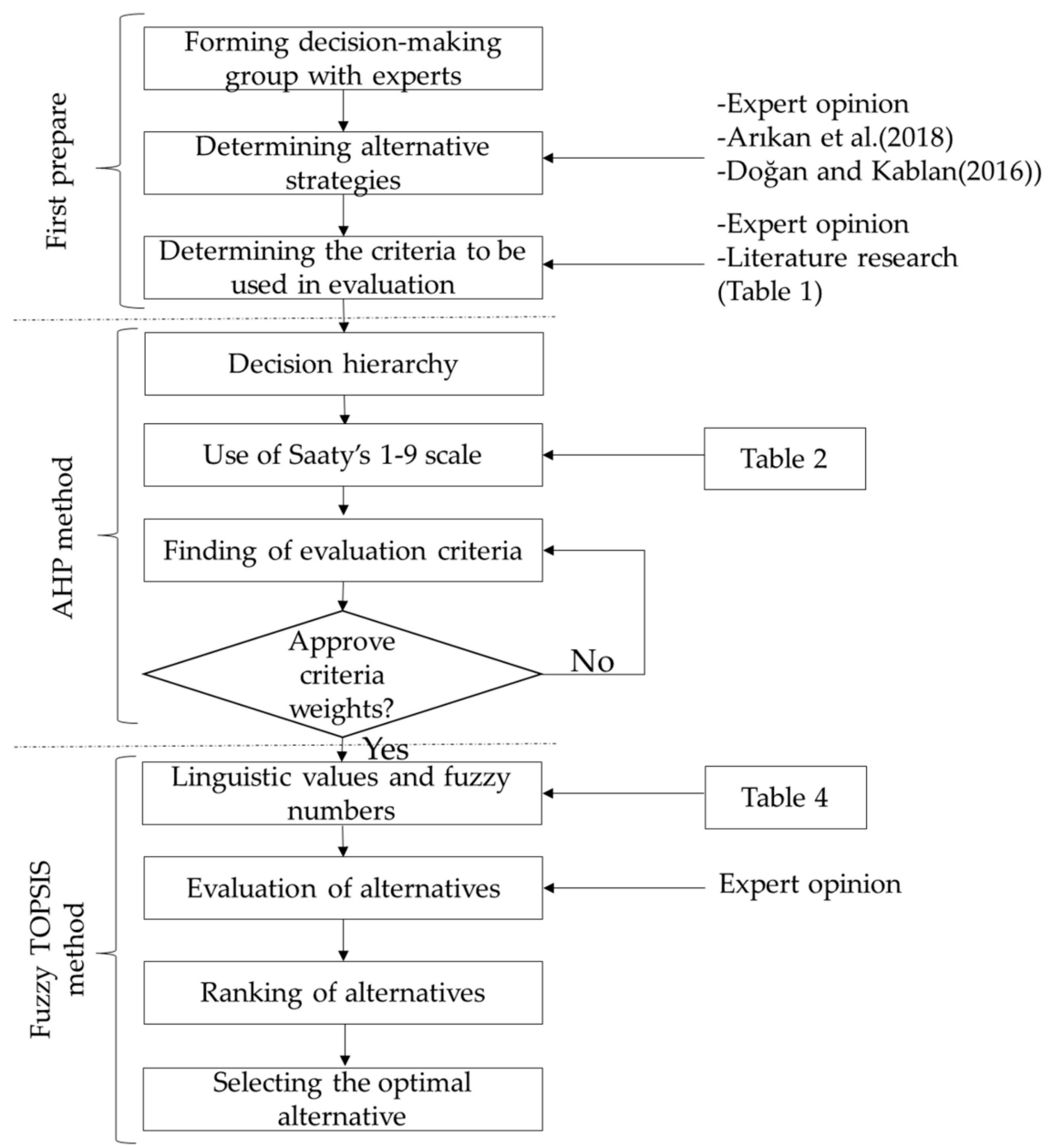

Figure 1. Schematic diagram of the proposed model for strategy selection.

The ranking of alternative strategies was determined using the fuzzy TOPSIS method in the third stage. Linguistic values were used for the evaluation of alternative strategies in this step. The membership functions of these linguistic values and the fuzzy triangular numbers are shown in Table 4. The criteria to be considered in the selection of transportation strategies were determined by literature research and by the expert team. Particularly, the academic literature on transportation decision-making had used lots of criteria.

The criteria used for this study were determined using literature research and according to expert opinion and county structure. The criteria and their definitions of importance are given in Table 5 . Following the determination of the criteria, and alternatives offered in literature, our new proposal for developing the current network by the decision-making team outlined three possible alternative strategies for the needs of the city. 
Table 5. The transportation sustainability criteria.

\begin{tabular}{cccc}
\hline Criteria & Sub-Criteria & Code & Reference \\
\hline \multirow{4}{*}{ Environment } & Noise pollution & C1 & Ignaccolo et al. (2019) [124] \\
& Visual effect & C2 & Wey \& Huang, (2018) [125] \\
& Air pollution & C3 & Lee (2018) [37] \\
Economic & Density of land use & C4 & Piantanakulchai \& Saengkhao \\
& Investment cost & C5 & $(2003)[126]$ \\
Social & Operation cost & C6 & Nosal \& Solecka (2014) [127] \\
& Acceptability & C7 & Awasthi et al. (2018) [128] \\
& Safety & C8 & Yang et al. (2016) [129] \\
& Impact on city congestion reduction & C9 & Cyril et al. (2019), [50] \\
Transport & Accessibility & C10 & Nassereddine \& Eskandari (2017) [5] \\
& Frequency of transport & C11 & Hamurcu et al. (2017) [130] \\
& Travel time & C12 & Hamurcu and Eren (2017) [131] \\
& Comfort & C13 & Hamurcu \& Eren (2019) [132] \\
\hline
\end{tabular}

\section{An Application of Decision-Making for Planning}

Kurıkkale is located at the crossing point of 43 provinces, $80 \mathrm{~km}$ away from Ankara, and approximately 1.15 hours away from Ankara. As one of the fastest-developing cities in terms of a growing population and economy, Kırıkkale is facing an increasing demand for transportation. Therefore, in the near future, it plans to invest in urban transportation to both meet its rapidly growing demand and reduce the number of special vehicles in the urban area. For this purpose, the Kirıkkale municipality faces an MCDM problem concerning what kind(s) of transportation mode to be adopted from among a set of options. They should make an investment preference to meet the demand and meet the city's needs. Electric municipality public buses, modernization of the current vehicle and transportation network, and the design of light rail system, three strong options among the possible options in the case of Kırıkkale, were determined [133].

To solve this problem, in this paper the proposed approach through the AHP and the fuzzy TOPSIS, defined in Section 3, was used to evaluate a set of proposed alternatives in terms of the evaluation criteria for Kırıkkale, in order to help transport or city planners to clearly explain how the approach works in a real-life case.

\subsection{The Proposed Alternative Projects}

The increasing population of cities and the growing mobility within cities have raised various problems. One of these problems is the rising transportation needs and traffic problems. Notably, one of the biggest dilemmas facing managers is how to solve the transportation problem with new concepts and practices. Considering the fact that fossil-fueled vehicles accelerate global warming and air pollution, the solution would need to include sustainable applications such as alternative-fueled vehicles and public transportation, and significant steps will need to be taken to create more livable cities. Making transport systems more efficient in terms of resource use on the basis of environmental sensitivity is an important factor in ensuring sustainability.

What is needed are long-term, comprehensive, and better plans and practices to establish cities along the principles of efficient and sustainable transport systems. Especially in developing cities that have not completed their transport infrastructure, it will be possible to create planned urbanization by ensuring sustainability through environmental, economic, and integrated transport plans. In this context, innovative initiatives and investments are also proposed to make urban transport sustainable in Kırıkkale. These recommendations include the light rail system proposal (Project-1), electric municipality public buses (Project-2), and the modernization of the current vehicle and transportation network (Project-3).

The minibuses in Kırıkkale city are operated by the private sector. At regular intervals, the minibuses operate between the city center and all its streets. Furthermore, in Kirikkale province there are 61,276 registered vehicles used for the transportation of passengers in the city. In addition, 
there was a significant increase in the number of cars and passenger traffic when considering intercity travel by private vehicles on the Kirıkkale-Samsun road. As a result of the fact that approximately 100,000 working people and around 40,000 students make inner-city transport journeys every day on urban connection roads which are essential for Kirıkkale province, it is seen that public rail transportation is needed [134].

Project 1: The design of light rail system (A1). The geographical location of the city, the high number of students, and the busy Kırıkkale-Ankara road have increased the traffic problems in the city. Together with all these, the Ankara-Sivas high-speed train, which is expected to be completed shortly, is expected to increase traffic problems in the province. Considering this, it has been suggested to add light rail systems to urban transportation in order to both ease the downtown traffic, to create the Osmangazi-University ring line, and to contribute to the environment in a context in which environmental problems are increasing [135].

Project 2: Electrical municipality public bus (A2). Today, problems such as rapid population growth, rapid urbanization rate, and emissions have also increased problems in the transportation sector. Proposing electric vehicles aims to ensure both environmental sustainability and city resident satisfaction. Further, the quality of services should be ensured by the municipality, with electric vehicles that more comfortable and environmentally friendly according to technical capacity.

Project 3: Modernization of the current vehicle and transportation network (A3). Kirıkkale is a city experiencing rapid urbanization. Expanding residential areas require new public transport lines. In addition, the existing public transportation lines are sometimes in conflict with each other. This situation also increases the damage to the environment with idle time and unnecessary fuel usage. Thus, the modernization of the current transportation network of Kirikkale must be developed. To improve the process, activities such as network optimization, route selection, demand forecasting, and multi-objective optimization for routes can be done.

\subsection{Identification of Sustainability Criteria for the Decision-Making Process}

The first step involves the selection of criteria for evaluating the sustainability of public transportation projects. Four categories of criteria were determined as economic, social, environmental, and transportation, and included their 14 sub-criteria. The information used to generate these criteria came from a literature review ([136-141] and Table 5) and discussions with experts in transportation area including five academics (one professor, two assistant professors, and two research assistants) and two transportation experts from the municipality.

The final list contains 14 sub-criteria under the four criteria in Table 5. In Table 5 above, the criteria $\mathrm{C} 1-\mathrm{C} 3, \mathrm{C} 4-\mathrm{C} 5-\mathrm{C} 6$, and $\mathrm{C} 12$ are the category criteria; that is, the lower the value, the more sustainable the alternative for the strategic decision-making process. The other criteria are benefited type criteria, that is, the higher the value, the more sustainable the public transportation.

We need quantitative data on social, economic, environmental, and transportation criteria for selection based on the sustainability of the public transportation projects in Kirıkkale. Since these applications are new and will be implemented in Kırıkkale, there is very limited quantitative data available, thereby making the evaluation process difficult. We benefited from using the fuzzy set theory due to this limitation.

To address this situation, a decision-making committee comprising of subject matter experts was formed who can use linguistic or qualitative ratings such as excellent, very high, high, medium, low, very low for assessing the alternatives and the criteria. Later, these qualitative assessments were transformed into fuzzy triangular numbers and then convert to crisp values (see Table 4).

The first goal was to analyze and identify the most relevant criteria/sub-criteria for transportation strategy selection. Depending on the needs of the city and its aims (environmental sustainability, economic sustainability, or effective use of resources), different criteria or sub-criteria were discussed in the literature, as shown in Table 5. 
Considering the above literature, the four criteria (environment, economic, social, and transport) and 14 sub-criteria $(\mathrm{C} 1, \mathrm{C} 2, \mathrm{C} 3, \mathrm{C} 4, \mathrm{C} 5, \mathrm{C} 6, \mathrm{C} 7, \mathrm{C} 8, \mathrm{C} 9, \mathrm{C} 10, \mathrm{C} 11, \mathrm{C} 12, \mathrm{C} 13$, and $\mathrm{C} 14)$ were proposed to the perspectives of the city planners. The proposed criteria and sub-criteria are presented in Figure 2 and described below in detail.

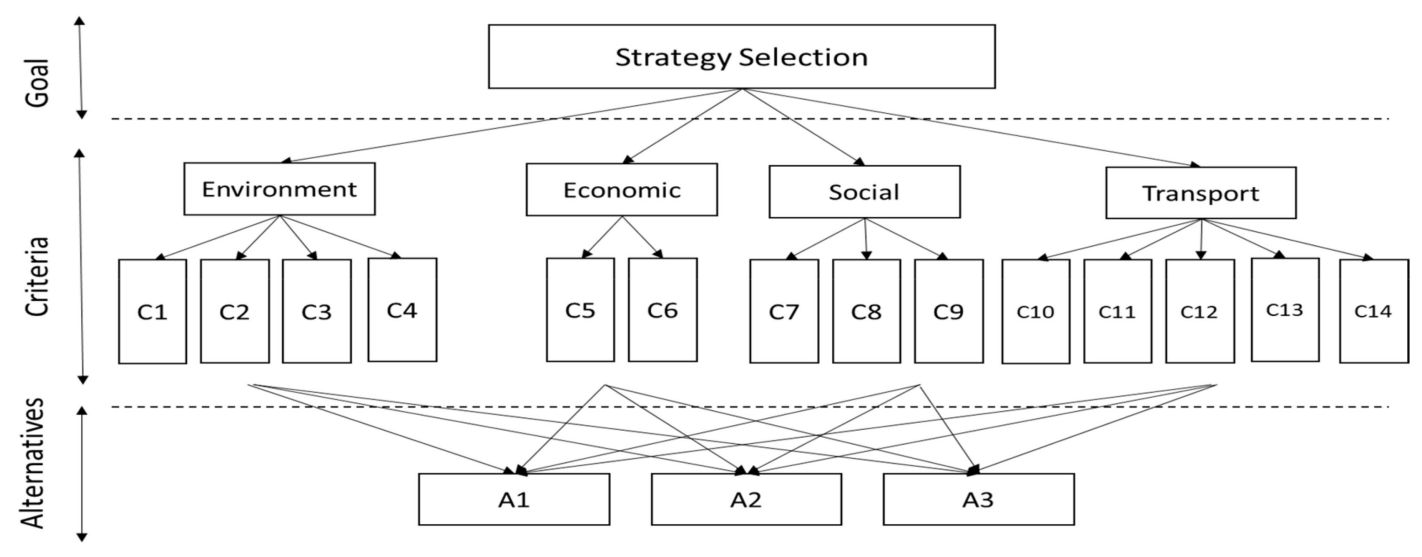

Figure 2. The decision hierarchy.

The environment criterion was divided into four sub-criteria: noise pollution, visual effect, air pollution, and density of land use. Noise pollution (C1) reflected a measure of the effecting of noise. The noise level differs in different alternative transportation types. Visual effect (C2) described the adaptation to the city structure. At the same time, this criterion was important to the acceptableness of projects by city residents. Air pollution (C3) defined the effect of harmful gases on the environment. Cleaner technologies are the reason for the preference for the environment. The density of land use (C4) reflected a measure of land use for alternative transportation types.

The economy is the main criterion examined by many researchers. This criterion is important for sustainability evaluation and may be considered as a mandatory criterion. The economic criterion was related to investment and operating costs. The investment cost (C5) described the initial construction cost, one of the most important criteria for investment. The operating costs (C6) represented the financial needs in the operation process. It is very important that a system maintains sustainability with the required resources.

The social criterion considered social effects such as acceptability, safety, and traffic congestion. Acceptability (C7) is one of the most important criteria for the evaluation of an investment in urban areas, because projects such as transportation deal with society directly. Safety (C8) was related to the road system and transportation system type. The impact on congestion (C9) denoted the reduction of car use in the urban area.

Another critical criterion was transportation. Accessibility (C10) was interpreted in terms of walking distance and proximity to important points. The frequency of transport (C11) was the number of trips in a day. The travel time (C12) dealt with the speed of the transportation systems, which is an important factor for both the planners and passengers. Comfort (C13) meant new, relaxing, and comfortable vehicles that reflects passenger demands. The vehicle occupancy (C14) meant the preference for transportation with larger capacities. Planners aim to reduce the unit cost per tour and maximize revenue.

\subsection{Calculate the Weights of Criteria}

After the determination of alternatives and evaluation criteria, decision hierarchy was established and shown in Figure 2. The decision hierarchy is shown in Figure 2. The top level of the decision hierarchy was defined as the goal of the problem. In this hierarchy, the aim of the study was strategy selection. The second level involved the evaluation criteria, the four main criteria and the 14 sub-criteria. For this hierarchy, the last level includes alternatives strategies for transportation 
problems. The pairwise comparison matrix using expert opinion for the main criteria is shown in Table 6. The normalization matrix for the main criteria and their eigenvector values are shown in Table 7. Then, important weights for each criterion were found for each criterion. These local and global weights of criteria and their consistency ratio are shown in Table 8. The results of the AHP determined that the most important main criteria were environmental, economic, social, and transport. The most important sub-criteria, according to global weights, were C1 and C3.

Table 6. The pairwise comparison matrix for the main criteria.

\begin{tabular}{ccccc}
\hline Criteria & Environment & Economic & Social & Transport \\
\hline Environment & 1.000 & 3.000 & 3.000 & 5.000 \\
Economic & 0.333 & 1.000 & 1.000 & 3.000 \\
Social & 0.333 & 1.000 & 1.000 & 3.000 \\
Transport & 0.200 & 0.333 & 0.333 & 1.000 \\
Total & 1.867 & 5.333 & 5.333 & 12.000 \\
\hline
\end{tabular}

Table 7. The normalization matrix for the main criteria.

\begin{tabular}{ccccccc}
\hline Criteria & Environment & Economic & Social & Transport & Total & Eigenvector \\
\hline Environment & 0.5356 & 0.5625 & 0.5625 & 0.4167 & 2.0774 & 0.5193 \\
Economic & 0.1784 & 0.1875 & 0.1875 & 0.2500 & 0.8034 & 0.2009 \\
Social & 0.1784 & 0.1875 & 0.1875 & 0.2500 & 0.8034 & 0.2009 \\
Transport & 0.1071 & 0.0624 & 0.0624 & 0.0833 & 0.3153 & 0.0789 \\
\hline
\end{tabular}

Table 8. Result obtained with AHP.

\begin{tabular}{|c|c|c|c|c|c|c|}
\hline Criteria & Weights & CI-RI & Sub-Criteria & Local Weights & CR & Global Weights \\
\hline \multirow{4}{*}{ Environment } & \multirow{4}{*}{0.51935} & \multirow{14}{*}{$\begin{array}{c}\lambda_{\max }=4.0435 \\
\mathrm{CI}=0.0145 \\
\mathrm{RI}=0.016\end{array}$} & $\mathrm{C} 1$ & 0.3648 & \multirow{4}{*}{0.0586} & 0.1894 \\
\hline & & & C2 & 0.1716 & & 0.0891 \\
\hline & & & C3 & 0.3648 & & 0.1894 \\
\hline & & & $\mathrm{C} 4$ & 0.0989 & & 0.0513 \\
\hline \multirow{2}{*}{ Economic } & \multirow{3}{*}{0.20089} & & $\mathrm{C5}$ & 0.6000 & - & 0.1205 \\
\hline & & & C6 & 0.4000 & & 0.0804 \\
\hline \multirow{3}{*}{ Social } & & & $\mathrm{C} 7$ & 0.2605 & \multirow{3}{*}{0.0334} & 0.0523 \\
\hline & \multirow[t]{2}{*}{0.20089} & & $\mathrm{C} 8$ & 0.6333 & & 0.1272 \\
\hline & & & C9 & 0.1062 & & 0.0213 \\
\hline \multirow{5}{*}{ Transport } & \multirow{5}{*}{0.07887} & & C10 & 0.2843 & \multirow{5}{*}{0.0941} & 0.0224 \\
\hline & & & C11 & 0.2405 & & 0.0190 \\
\hline & & & C12 & 0.2137 & & 0.0169 \\
\hline & & & $\mathrm{C} 13$ & 0.1902 & & 0.0150 \\
\hline & & & $\mathrm{C} 14$ & 0.0712 & & 0.0056 \\
\hline
\end{tabular}

The consistency ratio of the pairwise comparison matrix was calculated as 0.0586-0.0334-0.0941 < 0.1 for each comparison matrix. So, the weights are shown to be consistent, and they are used in the selection process.

\subsection{Evaluation Process with Fuzzy TOPSIS}

At this stage of the decision-making process, the expert team members compared alternatives under each of the criteria separately by linguistic variables. The beginning decision matrix was established for fuzzy TOPSIS. The fuzzy evaluation matrix is presented in Table 9. After the fuzzy evaluation matrix was determined, the second step was to obtain a fuzzy weighted decision table. In this step, using the criteria weights calculated by AHP (as shown in Table 8) the weighted evaluation matrix was established with AHP. The resulting fuzzy weighted decision matrix is shown in Table 10. 
Table 9. Fuzzy evaluation matrix for the alternative strategies.

\begin{tabular}{|c|c|c|c|c|c|c|c|}
\hline Alt. & $\begin{array}{c}\text { C1 } \\
\text { Min }\end{array}$ & $\begin{array}{c}\text { C2 } \\
\text { Min }\end{array}$ & $\begin{array}{c}\text { C3 } \\
\text { Min }\end{array}$ & $\begin{array}{c}\text { C4 } \\
\text { Min }\end{array}$ & $\begin{array}{c}\text { C5 } \\
\text { Min }\end{array}$ & $\begin{array}{c}\text { C6 } \\
\text { Min }\end{array}$ & $\begin{array}{c}\text { C7 } \\
\operatorname{Max}\end{array}$ \\
\hline A1 & Medium & High & Very low & Medium & High & Medium & High \\
\hline A3 & High & Low & High & High & Medium & High & Low \\
\hline A1 & $(0.2,0.4,0.6)$ & $(0.4,0.6,0.8)$ & $(0.0,0.0,0.2)$ & $(0.2,0.4,0.6)$ & $(0.4,0.6,0.8)$ & $(0.2,0.4,0.6)$ & $(0.4,0.6,0.8)$ \\
\hline Weight & 0.1894 & 0.0891 & 0.1894 & 0.0513 & 0.1205 & 0.0804 & 0.0523 \\
\hline \multirow{2}{*}{ Alt. } & $\mathrm{C} 8$ & C9 & $\mathrm{C} 10$ & C11 & $\mathrm{C} 12$ & $\mathrm{C} 13$ & $\mathrm{C} 14$ \\
\hline & Max & Max & Max & Max & Min & Max & Max \\
\hline A1 & High & High & Medium & Medium & High & Very high & High \\
\hline A2 & Medium & Medium & High & High & Medium & High & High \\
\hline A3 & $(0.0,0.2,0.4)$ & $(0.2,0.4,0.6)$ & $(0.4,0.6,0.8)$ & $(0.4,0.6,0.8)$ & $(0.2,0.4,0.6)$ & $(0.0,0.2,0.4)$ & $(0.2,0.4,0.6)$ \\
\hline Weight & 0.1272 & 0.0213 & 0.0224 & 0.0190 & 0.0169 & 0.0150 & 0.0056 \\
\hline
\end{tabular}

Table 10. Weighted evaluation for the alternative strategies.

\begin{tabular}{cccccccc}
\hline Alt. & $\mathrm{C} 1$ & $\mathrm{C} 2$ & $\mathrm{C} 3$ & $\mathrm{C} 4$ & $\mathrm{C} 5$ & $\mathrm{C} 6$ & $\mathrm{C} 7$ \\
\hline & $(0.038,0.076$, & $(0.036,0.053$, & $(0.000,0.038$, & $(0.010,0.021$, & $(0.048,0.072$, & $(0.016,0.032$, & $(0.021,0.031$, \\
A1 & $0.114)$ & $0.071)$ & $0.076)$ & $0.031)$ & $0.096)$ & $0.048)$ & $0.042)$ \\
& $(0.000,0.038$, & $(0.000,0.018$, & $(0.000,0.038$, & $(0.021,0.031$, & $(0.048,0.072$, & $(0.016,0.032$, & $(0.021,0.031$, \\
A2 & $0.076)$ & $0.036)$ & $0.076)$ & $0.041)$ & $0.096)$ & $0.048)$ & $0.042)$ \\
& $(0.076,0.114$, & $(0.000,0.018$, & $(0.076,0.114$, & $(0.021,0.031$, & $(0.024,0.048$, & $(0.032,0.048$, & $(0.000,0.010$, \\
A3 & $0.152)$ & $0.036)$ & $0.152)$ & $0.041)$ & $0.072)$ & $0.064)$ & $0.021)$ \\
A $^{+}$ & $(0,0,0)$ & $(0,0,0)$ & $(0,0,0)$ & $(0.2,0.2,0.2)$ & $(0.2,0.2,0.2)$ & $(0.2,0.2,0.2)$ & $(0.8,0.8,0.8)$ \\
A $^{-}$ & $(0.8,0.8,0.8)$ & $(0.8,0.8,0.8)$ & $(0.8,0.8,0.8)$ & $(0.8,0.8,0.8)$ & $(0.8,0.8,0.8)$ & $(0.8,0.8,0.8)$ & $(0,0,0)$ \\
\hline Alt. & $\mathrm{C} 8$ & $\mathrm{C} 9$ & $\mathrm{C} 10$ & $\mathrm{C} 11$ & $\mathrm{C} 12$ & $\mathrm{C} 13$ & $\mathrm{C} 14$ \\
\hline & $(0.051,0.076$, & $(0.009,0.013$, & $(0.004,0.009$, & $(0.004,0.008$, & $(0.007,0.010$, & $(0.009,0.012$, & $(0.002,0.003$, \\
A1 & $0.102)$ & $0.017)$ & $0.013)$ & $0.011)$ & $0.013)$ & $0.015)$ & $0.004)$ \\
& $(0.025,0.051$, & $(0.004,0.009$, & $(0.009,0.013$, & $(0.008,0.011$, & $(0.003,0.007$, & $(0.006,0.009$, & $(0.002,0.003$, \\
A2 & $0.076)$ & $0.013)$ & $0.018)$ & $0.015)$ & $0.010)$ & $0.012)$ & $0.004)$ \\
& $(0.000,0.025$, & $(0.004,0.009$, & $(0.009,0.013$, & $(0.008,0.011$, & $(0.003,0.007$, & $(0.000,0.003$, & $(0.001,0.002$, \\
A3 & $0.051)$ & $0.013)$ & $0.018)$ & $0.015)$ & $0.010)$ & $0.006)$ & $0.003)$ \\
A ${ }^{+}$ & $(0.8,0.8,0.8)$ & $(0.8,0.8,0.8)$ & $(0.8,0.8,0.8)$ & $(0.8,0.8,0.8)$ & $(0.2,0.2,0.2)$ & $(1,1,1)$ & $(0.8,0.8,0.8)$ \\
$\mathrm{A}^{-}$ & $(0.0,0.0,0.0)$ & $(0.2,0.2,0.2)$ & $(0.2,0.2,0.2)$ & $(0.2,0.2,0.2)$ & $(0.8,0.8,0.8)$ & $(0,0,0)$ & $(0.2,0.2,0.2)$ \\
\hline
\end{tabular}

According to Table 10 , it is seen that the elements $\widetilde{v}_{i j}, \forall i, j$ are normalized positive triangular fuzzy numbers, and their ranges belong to the closed interval $0-1$. In this transportation planning problem, $\mathrm{C} 1, \mathrm{C} 2, \mathrm{C} 3, \mathrm{C} 4, \mathrm{C} 5, \mathrm{C} 6$, and C12 are cost criteria, whereas the other criteria are benefit criteria. For the last step, the distance of each alternative from $d^{*}$ and $d^{-}$was currently calculated using Equation (12).

In order to illustrate steps 3 and 4 calculation, $\mathrm{CC}_{1}$ calculation is used as an example as follows. $d_{1}^{+}$ in Equation (20) and $d_{1}^{-}$in Equation (21) was found using Equation (17) and Equation (18) respectively. And finally, $C C_{1}$ in Equation (22) calculated by using Equation (19).

$$
\begin{gathered}
d_{1}^{+}=\sqrt{\frac{1}{3}\left[(0.0-0.038)^{2}+(0.0-0.076)^{2}+(0.0-0.114)^{2}\right]}+\ldots+ \\
\sqrt{\frac{1}{3}\left[(0.8-0.002)^{2}+(0.8-0.003)^{2}+(0.8-0.014)^{2}\right]}=6.5012 \\
d_{1}^{-}=\sqrt{\frac{1}{3}\left[(0.8-0.038)^{2}+(0.8-0.076)^{2}+(0.8-0.114)^{2}\right]}+\ldots+ \\
\sqrt{\frac{1}{3}\left[(0.2-0.002)^{2}+(0.2-0.003)^{2}+(0.2-0.014)^{2}\right]}=6.19088
\end{gathered}
$$




$$
C C_{1}^{*}=\frac{d_{1}^{-}}{d_{1}^{-}+d_{1}^{+}}=\frac{6.190883}{6.190883+6.5012}=0.4878
$$

Similar calculations were done for the other alternatives. The results of the fuzzy TOPSIS analyses are summarized in Table 11. Based on the CCj values, the ranking or the alternatives in descending order were A2, A1, and A3. The proposed model results indicate that A2 was the best alternative, with a $C$ C j value of 0.4910 .

Table 11. Fuzzy TOPSIS results.

\begin{tabular}{ccccc}
\hline Alternatives & $\mathbf{d}+$ & $\mathbf{d}-$ & $\mathbf{C C j}$ & Rank \\
\hline A1 & 6.5012 & 6.190883 & 0.4878 & 2 \\
A2 & 6.4534 & 6.226403 & 0.4910 & 1 \\
A3 & 6.6525 & 6.037536 & 0.4758 & 3 \\
\hline
\end{tabular}

The ranking results of each method of the case study are presented in Table 12. We conclude that, according to the described TOPSIS and hybrid fuzzy multiple criteria methodology, the best alternative was A2* (electric buses) with the largest degree of satisfaction.

Table 12. Weighted and unweighted rankings.

\begin{tabular}{ccccc}
\hline Alternatives & Weighted CC $\mathbf{j}$ & Rank & Unweighted CCj & Unweighted Ranking \\
\hline A1 & 0.4878 & 2 & 0.5585 & 2 \\
A2 & 0.4910 & 1 & 0.5909 & 1 \\
A3 & 0.4758 & 3 & 0.4250 & 3 \\
\hline
\end{tabular}

When comparing the CCi values of the alternatives in Table 12, we can see that $\mathrm{A} 2>\mathrm{A} 1>\mathrm{A} 3$ for every two processes. So, A2 (electric buses) is recommended as the best selection for the Kırıkkale city.

The weights of evaluation criteria indicate that noise and air pollution, under the environmental effect main criterion; cost, under the economic main criterion; safety, under the social main criterion; and, accessibility, under the transport main criterion, are the most important factors affecting the selection process. So there need to be lower cost, sustainable investments in developing cities. Electric buses with electric energy are cleaner technologies in comparison to current alternatives. However, their capacities for urban transportation are not high compared to rail systems. However, these cleaner technologies have been preferred over the more costly rail systems for developing cities, especially small cities, because of the advantages of accessibility and flexibility in the transportation network. Further, one of the problem alternatives, the modernization of the current vehicle and transportation network (A3), did not seem appropriate as a sustainable solution among the alternatives due to environmental sensitivity based on fuel type. The use of AHP did not improve the fuzzy TOPSIS results. However, the results of the fuzzy TOPSIS method have parallels with importance of criteria weights found using AHP and have supported each other.

In this study, two MCDM methods were used. The classic AHP method was courted in terms of shorter calculate time to find the importance of criteria wights due to the high number of criteria in the decision process. While the AHP ensured a shorter calculate time, the TOPSIS method also presented a rational and understandable decision process considering linguistic labels for the ranking of alternatives in this problem.

\section{Conclusions}

In this paper, we proposed a fuzzy TOPSIS method based on the AHP approach for the transportation planning process as it allows for preferences to be quantified and modeled, taking into account both qualitative and quantitative features of transportation options. 
As the engine of social and economic development, urban transport serves to provide accessibility and mobility for the cities of the world to survive and thrive. The rapid growth of the urban population, more and more per year in most developing cities, puts a strain on the urban transportation system. sustainable solutions in urban transportation are needed for developing cities. Sustainable urban transport solutions have incurred high social, environmental, and economic costs in developing cities.

Transportation planning studies are being used more and more in order to produce high-scale solutions to increasing urban transportation problems in developed and developing cities. It is necessary to deal with different factors and evaluation criteria to find the most suitable solution to transportation problems. MCDM methods are good techniques for evaluation. The AHP and TOPSIS, the methods that can be used to compare alternatives in transportation planning, were examined briefly in the scope of this study and were applied in the selection of the alternatives.

The proposed method may be applied to any stage of the planning process. In this study, we discussed the strategic planning process for transportation planning. The involvement of the proposed decision-making model in these stages significantly helped the planning process in two ways: its stages included simple mathematical operations, and modeling via fuzzy numbers enabled the use of linguistic variables. Finally, the proposed methodology was applied to compare and rank real alternative transportation options that would increase the accessibility and the air quality of the center of the Kırıkkale. The proposed model results gave a reasonable ranking, which were consistent with each other, though with different reciprocal weights. Finally, the result of our study selected the implementation of an electric bus in the city center of Kirıkkale as the best among the three alternatives.

Proactive transportation planning is a very important issue for developing cities because of the need for a more livable environment and city center. Using various analytic methods are also critical.

Future studies can be made on network planning, capacity planning, and the measurement of performance for alternative public transportation. Public participation and stakeholder engagement, which are the two most important factors, can be added to the evaluation process for transportation. This can be established by mathematical models such as linear programming and goal programming. These optimization models can be integrated with fuzzy MCDM methods. Finally, mathematical and analytic decision processes should be generalized in the various management departments of municipalities for better and more effective decision-making. The proposed AHP-fuzzy TOPSIS methods, with minor modifications, can be useful to all municipalities in their strategy selection decisions.

Author Contributions: Conceptualization, M.H. and M.H.; methodology, M.H..; validation, M.H.and T.E.; formal analysis, M.H.; investigation, M.H.; resources, M.H.; writing—original draft preparation, M.H.; writing-review and editing, M.H. and T.E.; supervision, T.E.; project administration, M.H. and T.E. All authors have read and agreed to the published version of the manuscript.

Funding: This research received no external funding.

Conflicts of Interest: The authors declare no conflicts of interest.

\section{Nomenclature-Acronyms and Symbols}

$\begin{array}{ll}\text { AHP } & \text { analytic hierarchy process } \\ \text { TOPSIS } & \text { technique for order preference by similarity to ideal situation } \\ \text { LR } & \text { literature review } \\ \text { BWM } & \text { best worst method } \\ \text { MCA } & \text { multi-criteria analysis } \\ \text { MCDM } & \text { multi-criteria decision making }\end{array}$




$\begin{array}{ll}\text { MP } & \text { mathematical programming } \\ \text { GIS } & \text { geographical information systems } \\ \text { PROMETHEE } & \text { preference ranking organization method for enrichment and evaluations } \\ \text { ELECTRE } & \text { elimination et choix traduisant la realité } \\ \text { VIKOR } & \text { intekriterijumsko kompromisno rangiranje } \\ \text { IVIF } & \text { combinative distance-based assessment } \\ \text { CODAS } & \text { multi-objective optimization on the basis of ratio analysis } \\ \text { MOORA } & \text { characteristic objects method } \\ \text { COMET } & \text { fuzzy analytic hierarchy process } \\ \text { FAHP } & \text { goal programming } \\ \text { GP } & \text { the linear goal programming priority based fuzzy analytic hierarchy process } \\ \text { LGPPFAHP } & \text { fuzzy group multi-attribute decision analysis } \\ \text { FGMADA } & \text { fuzzy multi-criteria decision making } \\ \text { FMCDM } & \text { consistency ratio } \\ \text { CR } & \text { consistency index } \\ \text { CI } & \text { random index } \\ \text { RI } & \text { fuzzy positive-ideal solution } \\ \text { FPIS } & \text { fuzzy negative-ideal solution } \\ \text { FNIS } & \end{array}$

\section{References}

1. Liang, H.; Ren, J.; Lin, R.; Liu, Y. Alternative-fuel based vehicles for sustainable transportation: A fuzzy group decision supporting framework for sustainability prioritization. Technol. Forecast. Soc. Chang. 2019, 140, 33-43. [CrossRef]

2. Fan, P.; Ouyang, Z.; Nguyen, D.D.; Nguyen, T.T.H.; Park, H.; Chen, J. Urbanization, economic development, environmental and social changes in transitional economies: Vietnam after Doimoi. Landsc. Urban Plan. 2019, 187, 145-155. [CrossRef]

3. Cascetta, E.; Carteni, A.; Pagliara, F.; Montanino, M. A new look at planning and designing transportation systems: A decision-making model based on cognitive rationality, stakeholder engagement and quantitative methods. Transp. Policy 2015, 38, 27-39. [CrossRef]

4. Shang, J.; Tjader, Y.; Ding, Y. A Unified Framework for Multicriteria Evaluation of Transportation Projects. IEEE Trans. Eng. Manag. 2004, 51, 300-313. [CrossRef]

5. Nassereddine, M.; Eskandari, H. An integrated MCDM approach to evaluate public transportation systems in Tehran. Transp. Res. Part A: Policy Pract. 2017, 106, 427-439. [CrossRef]

6. Black, W. Sustainable Transportation: Problems and Solutions; Guilford Press: New York, NY, USA, 2010.

7. Chapman, L. Transport and climate change: A review. J. Transp. Geogr. 2007, 15, 354-367. [CrossRef]

8. Downs, A. Stuck in Traffic: Coping with Peak-Hour Traffic Congestion; The Brookings Institution: Washington, DC, USA, 2005.

9. Site, P.D.; Filippi, F. Weighting methods in multi-attribute assessment of transport projects. Eur. Transp. Res. Rev. 2009, 1, 199-206. [CrossRef]

10. Saaty, T.L. Fundamentals of Decision Making and Priority Theory with the Analytic Hierarchy Process, 1st ed.; RWS Publications: Pittsburgh, PA, USA, 2000.

11. Lai, Y.J.; Liu, T.Y.; Hwang, C.L. Topsis for MODM. Eur. J. Oper. Res. 1994, 76, 486-500. [CrossRef]

12. Zadeh, L. Fuzzy sets. Inf. Control 1965, 8, 338-353. [CrossRef]

13. Canitez, F. Pathways to sustainable urban mobility in developing megacities: A socio-technical transition perspective. Technol. Forecast. Soc. Chang. 2019, 141, 319-329. [CrossRef]

14. Cervero, R. Linking urban transport and land use in developing countries. J. Transp. Land Use 2013, 6, 7. [CrossRef]

15. Phun, V.K.; Kato, H.; Chalermpong, S. Paratransit as a connective mode for mass transit systems in Asian developing cities: Case of Bangkok in the era of ride-hailing services. Transp. Policy 2019, 75, 27-35. [CrossRef]

16. Gerçek, H.; Karpak, B.; Kılınçaslan, T. A multiple criteria approach for the evaluation of the rail transit networks in Istanbul. Transportation 2004, 31, 203-228. [CrossRef] 
17. Jones, S., Jr.; Tefe, M.; Appiah-Opoku, S. Proposed framework for sustainability screening of urban transport projects in developing countries: A case study of Accra, Ghana. Transp. Res. Part A: Policy Pract. 2013, 49, 21-34. [CrossRef]

18. Barbosa, S.B.; Ferreira, M.G.G.; Nickel, E.M.; Cruz, J.A.; Forcellini, F.A.; Garcia, J.; de Andrade, J.B.S.O. Multi-criteria analysis model to evaluate transport systems: An application in Florianópolis, Brazil. Transp. Res. Part. A: Policy Pract. 2017, 96, 11-13. [CrossRef]

19. Sayyadi, R.; Awasthi, A. A system dynamics based simulation model to evaluate regulatory policies for sustainable transportation planning. Int. J. Model. Simul. 2016, 37, 25-35. [CrossRef]

20. Guine, J.B. Handbook on Life Cycle Analysis. An Operational Guide to the ISO Standard. Springer Netherlands: Dordrecht, The Netherlands, 2002.

21. Eliasson, J.; Fosgerau, M. Cost-benefit analysis of transport improvements in the presence of spillovers, matching and an income tax. Econ. Transp. 2019, 18, 1-9. [CrossRef]

22. Dalke, D.; Prusak, J.; Woodside, G. Product Environmental Impact Assessments; Institute of Electrical and Electronics Engineers (IEEE): Piscataway, NJ, USA, 2002.

23. Sayyadi, R.; Awasthi, A. A simulation-based optimisation approach for identifying key determinants for sustainable transportation planning. Int. J. Syst. Sci. Oper. Logist. 2016, 5, 161-174. [CrossRef]

24. Lima, J.P.; Lima, R.D.S.; Da Silva, A.N.R. Evaluation and Selection of Alternatives for the Promotion of Sustainable Urban Mobility. Proc. Soc. Behav. Sci. 2014, 162, 408-418. [CrossRef]

25. Tyagi, S.; Agrawal, S.; Yang, K.; Ying, H. An extended Fuzzy-AHP approach to rank the influences of socialization-externalization-combination-internalization modes on the development phase. Appl. Soft Comput. 2017, 52, 505-518. [CrossRef]

26. Browne, D.; Ryan, L. Comparative analysis of evaluation techniques for transport policies. Environ. Impact Assess. Rev. 2011, 31, 226-233. [CrossRef]

27. Macharis, C.; Bernardini, A. Reviewing the use of Multi-Criteria Decision Analysis for the evaluation of transport projects: Time for a multi-actor approach. Transp. Policy 2015, 37, 177-186. [CrossRef]

28. Giuffrida, N.; Pira, L.; Inturri, G.; Ignaccolo, M.; Le Pira, M. Mapping with Stakeholders: An Overview of Public Participatory GIS and VGI in Transport Decision-Making. ISPRS Int. J. Geoinf. 2019, 8, 198. [CrossRef]

29. Stojčić, M.; Zavadskas, E.K.; Pamučar, D.; Stević, Ž; Mardani, A. Application of MCDM Methods in Sustainability Engineering: A Literature Review 2008-2018. Symmetry 2019, 11, 350. [CrossRef]

30. Pérez, J.C.; Carrillo, M.H.; Montoya-Torres, J.R. Multi-criteria approaches for urban passenger transport systems: A literature review. Ann. Oper. Res. 2014, 226, 69-87. [CrossRef]

31. Mahmoudi, R.; Shetab-Boushehri, S.-N.; Hejazi, S.R.; Emrouznejad, A. Determining the relative importance of sustainability evaluation criteria of urban transportation network. Sustain. Cities Soc. 2019, 47, 101493. [CrossRef]

32. Barfod, M.B.; Salling, K.B. A new composite decision support framework for strategic and sustainable transport appraisals. Transp. Res. Part A: Policy Pract. 2015, 72, 1-15. [CrossRef]

33. Khayamim, R.; Shetab-Boushehrib, S.-N.; Hosseininasab, S.-M.; Karimi, H. A sustainable approach for selecting and timing the urban transportation infrastructure projects in large-scale networks: A case study of Isfahan, Iran. Sustain. Cities Soc. 2020, 53, 101981. [CrossRef]

34. Özcan, E.; Hamurcu, M.; Alakaş, H.M.; Eren, T. Project selection by using constraint programming. J. Trends Dev. Mach. Assoc. Technol. 2018, 21, 899-902.

35. Lambas, M.E.L.; Giuffrida, N.; Ignaccolo, M.; Inturri, G.; Ricci, S.; Brebbia, C.A. Comparison Between Bus Rapid Transit and Light-Rail Transit Systems: A Multi-Criteria Decision Analysis Approach. Urb. Transp. XXIII 2017, 1, 143-154. [CrossRef]

36. Wu, Y.; Yang, M.; Zhang, H.; Chen, K.; Wang, Y. Optimal Site Selection of Electric Vehicle Charging Stations Based on a Cloud Model and the PROMETHEE Method. Energies 2016, 9, 157. [CrossRef]

37. Lee, D.-J. A multi-criteria approach for prioritizing advanced public transport modes (APTM) considering urban types in Korea. Transp. Res. Part A: Policy Pract. 2018, 111, 148-161. [CrossRef]

38. Mohammadi, A.; Amador-Jimenez, L.; Nasiri, F. A multi-criteria assessment of the passengers' level of comfort in urban railway rolling stock. Sustain. Cities Soc. 2020, 53, 101892. [CrossRef]

39. Li, C.; Negnevitsky, M.; Wang, X.; Yue, W.L.; Zou, X. Multi-criteria analysis of policies for implementing clean energy vehicles in China. Energy Policy 2019, 129, 826-840. [CrossRef] 
40. Hickman, R.; Saxena, S.; Banister, D.; Ashiru, O. Examining transport futures with scenario analysis and MCA. Transp. Res. Part A Policy Pract. 2012, 46, 560-575. [CrossRef]

41. Seker, S.; Aydin, N. Sustainable Public Transportation System Evaluation: A Novel Two-Stage Hybrid Method Based on IVIF-AHP and CODAS. Int. J. Fuzzy Syst. 2020, 22, 257-272. [CrossRef]

42. Keyvan Ekbatani, M.; Cats, O. Multi-criteria appraisal of multi-modal urban public transport systems. In Proceedings of the Transportation Research Procedia, 18th Euro Working Group on Transportation, EWGT 2015, Delft, The Netherlands, 14-16 July 2015.

43. Yedla, S.; Shrestha, R.M. Multi-criteria approach for the selection of alternative options for environmentally sustainable transport system in Delhi. Transp. Res. Part A: Policy Pract. 2003, 37, 717-729. [CrossRef]

44. Hamurcu, M.; Eren, T. Electric Bus Selection with Multicriteria Decision Analysis for Green Transportation. Sustainability 2020, 12, 2777. [CrossRef]

45. Hamurcu, M.; Eren, T. Applications of the MOORA and TOPSIS Method for Decision of Electric Vehicle in Public Transportation Technology. Transportation 2020. (In press)

46. Sałabun, W.; Palczewski, K.; Wątróbski, J. Multicriteria Approach to Sustainable Transport Evaluation under Incomplete Knowledge: Electric Bikes Case Study. Sustainability 2019, 11, 3314. [CrossRef]

47. Dinç, S.; Hamurcu, M.; Eren, T. Kentsel Ulaşım İçin Alternatif Tramvay Araçlarının Çok Kriterli Seçimi. Gazi Mühendislik Bilimleri Dergisi (GMBD) 2018, 4, 124-135.

48. Hamurcu, M.; Eren, T. Selection of monorail technology by using multicriteria decision making. Sigma J. Eng. Nat. Sci. 2017, 8, 3033-3044.

49. Kumar, A.; Aswin, A.; Gupta, H. Evaluating green performance of the airports using hybrid BWM and VIKOR methodology. Tour. Manag. 2020, 76, 103941. [CrossRef]

50. Cyril, A.; Mulangi, R.H.; George, V. Performance Optimization of Public Transport Using Integrated AHP-GP Methodology. Urb. Rail Transit 2019, 1-12. [CrossRef]

51. Pedroso, G.; Bermann, C.; Pereira, A.S. Combining the functional unit concept and the analytic hierarchy process method for performance assessment of public transport options. Case Stud. Transp. Policy 2018, 6, 722-736. [CrossRef]

52. Aydin, N. A fuzzy-based multi-dimensional and multi-period service quality evaluation outline for rail transit systems. Transp. Policy 2017, 55, 87-98. [CrossRef]

53. Celik, E.; Aydin, N.; Gumus, A.T. A multiattribute customer satisfaction evaluation approach for rail transit network: A real case study for Istanbul, Turkey. Transp. Policy 2014, 36, 283-293. [CrossRef]

54. D'Arcier, B.F. Measuring the performance of urban public transport in relation to public policy objectives. Res. Transp. Econ. 2014, 48, 67-76. [CrossRef]

55. Mahmoud, M.; Hine, J. Using AHP to measure the perception gap between current and potential users of bus services. Transp. Plan. Technol. 2013, 36, 4-23. [CrossRef]

56. Ullah, K.; Hamid, S.; Mirza, F.M.; Shakoor, U. Prioritizing the gaseous alternatives for the road transport sector of Pakistan: A multi criteria decision making analysis. Energy 2018, 165, 1072-1084. [CrossRef]

57. Büyüközkan, G.; Feyzioğlu, O.; Göçer, F. Selection of sustainable urban transportation alternatives using an integrated intuitionistic fuzzy Choquet integral approach. Transp. Res. Part D: Transp. Environ. 2018, 58, 186-207. [CrossRef]

58. Osorio-Tejada, J.L.; Llera-Sastresa, E.M.; Scarpellini, S. A multi-criteria sustainability assessment for biodiesel and liquefied natural gas as alternative fuels in transport systems. J. Nat. Gas Sci. Eng. 2017, 42, 169-186. [CrossRef]

59. Oztaysi, B.; Onar, S.C.; Kahraman, C.; Yavuz, M. Multi-criteria alternative-fuel technology selection using interval-valued intuitionistic fuzzy sets. Transp. Res. Part D Transp. Environ. 2017, 53, 128-148. [CrossRef]

60. Onat, N.C.; Gumus, S.; Kucukvar, M.; Tatari, O. Application of the TOPSIS and intuitionistic fuzzy set approaches for ranking the life cycle sustainability performance of alternative vehicle technologies. Sustain. Prod. Consum. 2016, 6, 12-25. [CrossRef]

61. Onat, N.C.; Kucukvar, M.; Tatari, O.; Zheng, Q. Combined application of multi-criteria optimization and life-cycle sustainability assessment for optimal distribution of alternative passenger cars in U.S. J. Clean. Prod. 2016, 112, 291-307. [CrossRef]

62. Mukherjee, S. Selection of Alternative Fuels for Sustainable Urban Transportation under Multi-criteria Intuitionistic Fuzzy Environment. Fuzzy Inf. Eng. 2017, 9, 117-135. [CrossRef] 
63. Lanjewar, P.B.; Rao, R.; Kale, A. Assessment of alternative fuels for transportation using a hybrid graph theory and analytic hierarchy process method. Fuel 2015, 154, 9-16. [CrossRef]

64. Shiau, T.-A. Evaluating sustainable transport strategies for the counties of Taiwan based on their degree of urbanization. Transp. Policy 2013, 30, 101-108. [CrossRef]

65. Ruiz, A.; Guevara, J. Sustainable decision-making in road development: Analysis of road preservation policies. Sustainability 2020, 12(3), 872. [CrossRef]

66. Gür, Ş.; Hamurcu, M.; Eren, T. Selecting of monorail projects with analytic hierarchy process and 01-goal programming methods in Ankara. Pamukkale Univ. J. Eng. Sci. 2017, 23, 437-443.

67. Luke, S.; MacDonald, M. Public transport mode selection: A review of international practice. In Proceedings of the European Transport Conference, Strasbourg, France,, 18-20 September 2006.

68. Hu, J.; Guo, X. Research on Public Transportation Development Model Selection in New Urban Areas. Chall. Adv. Sustain. Transp. Syst. 2014, 65-72. [CrossRef]

69. Hadas, Y.; Nahum, O.E. Urban bus network of priority lanes: A combined multi-objective, multi-criteria and group decision-making approach. Transp. Policy 2016, 52, 186-196. [CrossRef]

70. Lin, M.; Huang, C.; Xu, Z. MULTIMOORA based MCDM model for site selection of car sharing station under picture fuzzy environment. Sustain. Cities Soc. 2020, 53, 101873. [CrossRef]

71. Kumarage, A.S.; Weerawardana, J. System cost-based multi-criteria analysis for urban transport solutions. Int. J. Urban Sci. 2013, 17, 212-225. [CrossRef]

72. Schutte, I.C.; Brits, A. Prioritising transport infrastructure projects: Towards a multi-criterion analysis. South. Afr. Bus. Rev. 2012, 16, 971-977.

73. Duleba, S.; Mishina, T.; Shimazaki, Y. A dynamic analysis on public bus transport's supply quality by using AHP. Transportation 2012, 27, 268-275. [CrossRef]

74. Hassan, M.N.; Hawas, Y.E.; Ahmed, K. A multi-dimensional framework for evaluating the transit service performance. Transp. Res. Part A: Policy Pract. 2013, 50, 47-61. [CrossRef]

75. Macharis, C.; Van Hoeck, E.; Pekin, E.; Van Lier, T. A decision analysis framework for intermodal transport: Comparing fuel price increases and the internalisation of external costs. Transp. Res. Part A: Policy Pract. 2010, 44, 550-561. [CrossRef]

76. Tzeng, G.-H.; Lin, C.-W.; Opricovic, S. Multi-criteria analysis of alternative-fuel buses for public transportation. Energy Policy 2005, 33, 1373-1383. [CrossRef]

77. Vahdani, B.; Zandieh, M.; Tavakkoli-Moghaddam, R. Two novel FMCDM methods for alternative-fuel buses selection. Appl. Math. Model. 2011, 35, 1396-1412. [CrossRef]

78. Patil, A.; Herder, P.; Brown, K. Investment Decision Making for Alternative Fuel Public Transport Buses: The Case of Brisbane Transport. J. Public Transp. 2010, 13, 115-133. [CrossRef]

79. Majumder, M. Impact of Urbanization on Water Shortage in Face of Climatic Aberrations; Springer: Berlin/Heidelberg, Germany, 2015; pp. 35-48. [CrossRef]

80. Saaty, T.L. How to make a decision: The analytic hierarchy process. Eur. J. Oper. Res. 1990, 48, 9-26. [CrossRef]

81. Saaty, T.L. Decision making with the analytic hierarchy process. Int. J. Serv. Sci. 2008, 1, 83. [CrossRef]

82. Saaty, T.L. Decision making with dependence and feedback: The analytic network process. RWS Publ. 1996, 4922.

83. Brans, J.P.; Vincke, P. Note-A Preference Ranking Organisation Method. Manag. Sci. 1985, 31, $647-656$. [CrossRef]

84. Roy, B. The outranking approach and the foundations of electre methods. Theory Decis. 1991, 31, 49-73. [CrossRef]

85. Opricovic, S.; Tzeng, G.-H. Compromise solution by MCDM methods: A comparative analysis of VIKOR and TOPSIS. Eur. J. Oper. Res. 2004, 156, 445-455. [CrossRef]

86. Rezaei, J. Best-worst multi-criteria decision-making method. Omega 2015, 53, 49-57. [CrossRef]

87. Rezaei, J. Best-worst multi-criteria decision-making method: Some properties and a linear model. Omega 2016, 64, 126-130. [CrossRef]

88. Zaidan, A.A.; Zaidan, B.; Al-Haiqi, A.; Kiah, M.; Hussain, M.; Abdulnabi, M. Evaluation and selection of open-source EMR software packages based on integrated AHP and TOPSIS. J. Biomed. Inf. 2015, 53, 390-404. [CrossRef] 
89. Dinmohammadi, A.; Shafiee, M. Determination of the Most Suitable Technology Transfer Strategy for Wind Turbines Using an Integrated AHP-TOPSIS Decision Model. Energies 2017, 10, 642. [CrossRef]

90. Sindhu, S.; Nehra, V.; Luthra, S. Investigation of feasibility study of solar farms deployment using hybrid AHP-TOPSIS analysis: Case study of India. Renew. Sustain. Energy Rev. 2017, 73, 496-511. [CrossRef]

91. Karahalios, H. Pelorus The application of the AHP-TOPSIS for evaluating ballast water treatment systems by ship operators. Transp. Res. Part D Transp. Environ. 2017, 52, 172-184. [CrossRef]

92. Onut, S.; Soner, S. Transshipment site selection using the AHP and TOPSIS approaches under fuzzy environment. Waste Manag. 2008, 28, 1552-1559. [CrossRef]

93. Amiri, M.P. Project selection for oil-fields development by using the AHP and fuzzy TOPSIS methods. Expert Syst. Appl. 2010, 37, 6218-6224. [CrossRef]

94. Mandic, K.; Boris, D.; Snežana, K.; Sladjana, B. Analysis of the efficiency of insurance companies in Serbia using the fuzzy AHP and TOPSIS methods. Econ. Res. Ekonomska Istraživanja 2017, 30, 550-565. [CrossRef]

95. Dagdeviren, M.; Yavuz, S.; Kılınç, N. Weapon selection using the AHP and TOPSIS methods under fuzzy environment. Expert Syst. Appl. 2009, 36, 8143-8151. [CrossRef]

96. Ligus, M.; Peternek, P. Determination of most suitable low-emission energy technologies development in Poland using integrated fuzzy AHP-TOPSIS method. Energy Procedia 2018, 153, 101-106. [CrossRef]

97. Junior, F.R.L.; Osiro, L.; Carpinetti, L.C.R. A comparison between Fuzzy AHP and Fuzzy TOPSIS methods to supplier selection. Appl. Soft Comput. 2014, 21, 194-209. [CrossRef]

98. Kusumawardani, S.S.; Agintiara, M. Application of Fuzzy AHP-TOPSIS Method for Decision Making in Human Resource Manager Selection Process. Proc. Comput. Sci. 2015, 72, 638-646. [CrossRef]

99. Büyüközkan, G.; Çifçi, G. A combined fuzzy AHP and fuzzy TOPSIS based strategic analysis of electronic service quality in healthcare industry. Expert Syst. Appl. 2012, 39, 2341-2354. [CrossRef]

100. Sirisawat, P.; Kiatcharoenpol, T. Fuzzy AHP-TOPSIS approaches to prioritizing solutions for reverse logistics barriers. Comput. Ind. Eng. 2018, 117, 303-318. [CrossRef]

101. Hosseini, M.H.; Keshavarz, E. Using fuzzy AHP and fuzzy TOPSIS for strategic analysis measurement of service quality in banking industry. Int. J. Appl. Manag. Sci. 2017, 9, 55-80. [CrossRef]

102. Zyoud, S.H.; Kaufmann, L.G.; Shaheen, H.; Samhan, S.; Fuchs-Hanusch, D. A framework for water loss management in developing countries under fuzzy environment: Integration of Fuzzy AHP with Fuzzy TOPSIS. Expert Syst. Appl. 2016, 61, 86-105. [CrossRef]

103. Özcan, E.C.; Danışan, T.; Eren, T. A mathematical model proposal for maintenance strategies optimization of the most critical electrical equipment groups of hydroelectric power plants. Pamukkale Univ. J. Eng. Sci. 2019, 25, 498-506. [CrossRef]

104. Wang, T.-C.; Chang, T.-H. Application of TOPSIS in evaluating initial training aircraft under a fuzzy environment. Expert Syst. Appl. 2007, 33, 870-880. [CrossRef]

105. Kulak, O.; Durmuşoğlu, M.B.; Kahraman, C. Fuzzy multi-attribute equipment selection based on information axiom. J. Mater. Process. Technol. 2005, 169, 337-345. [CrossRef]

106. Taş, M.; Özlemiş, Ş.N.; Hamurcu, M.; Eren, T. Ankara'da AHP ve PROMETHEE yaklaşımıyla monoray hat tipinin belirlenmesi. Ekonomi İşletme Siyaset ve Uluslararası İlişkiler Dergisi 2017, 3, 65-89.

107. Eren, T.; Hamurcu, M. Akademik Teşvik Tabanlı Yeni Bir Performans Değerlendirme Önerisi ve Uygulama. Üniversite Araştırmaları Dergisi 2019, 2, 82-100. [CrossRef]

108. Bedir, N.; Alakaş, H.M.; Eren, T. A Disassembly Line Balancing with Multiciteria Decision Making. Int. J. Eng. Res. Dev. 2017, 9, 1-18.

109. Süt, N.İ.; Hamurcu, M.; Eren, T. Kampüste yeşil ulaşım uygulaması: Ring araçlarının seçimi için bir karar verme süreci. Gazi Mühendislik Bilimleri Dergisi (GMBD) 2019, 5, 9-21.

110. Nazari, S.; Fallah, M.; Kazemipoor, H.; Salehipour, A. A fuzzy inference- fuzzy analytic hierarchy process-based clinical decision support system for diagnosis of heart diseases. Expert Syst. Appl. 2018, 95, 261-271. [CrossRef]

111. Pishchulov, G.; Trautrims, A.; Chesney, T.; Gold, S.; Schwab, L. The Voting Analytic Hierarchy Process revisited: A revised method with application to sustainable supplier selection. Int. J. Prod. Econ. 2019, 211, 166-179. [CrossRef]

112. Xue, R.; Wang, C.; Liu, M.; Zhang, N.; Li, K.; Li, N. A new method for soil health assessment based on Analytic Hierarchy Process and meta-analysis. Sci. Total. Environ. 2019, 650, 2771-2777. [CrossRef] [PubMed] 
113. Saaty, T.L.; Gholamnezhad, H. High-Level Nuclear Waste Management: Analysis of Options. Environ. Plan. B: Plan. Des. 1982, 9, 181-196. [CrossRef]

114. Saaty, T.L. What is the Analytic Hierarchy Process? In Mathematical Models for Decision Support; Springer: Berlin/Heidelberg, Germany, 1988; pp. 109-121.

115. Saaty, T.L. Transport planning with multiple criteria: The analytic hierarchy process applications and progress review. J. Adv. Transp. 1995, 29, 81-126. [CrossRef]

116. Saaty, T.L. How to Make a Decision: The Analytic Hierarchy Process. Interfaces 1994, 24, 19-43. [CrossRef]

117. Hwang, C.-L.; Yoon, K. Multiple Attribute Decision Making. Lect. Notes Econ. Math. Syst. $1981,186$. [CrossRef]

118. Wang, Y.-M.; Elhag, T.M. Fuzzy TOPSIS method based on alpha level sets with an application to bridge risk assessment. Expert Syst. Appl. 2006, 31, 309-319. [CrossRef]

119. Ervural, B.C.; Zaim, S.; Demirel, O.F.; Aydin, Z.; Delen, D. An ANP and fuzzy TOPSIS-based SWOT analysis for Turkey's energy planning. Renew. Sustain. Energy Rev. 2018, 82, 1538-1550. [CrossRef]

120. Memari, A.; Dargi, A.; Jokar, M.R.A.; Ahmad, R.; Rahim, A.R.A. Sustainable supplier selection: A multi-criteria intuitionistic fuzzy TOPSIS method. J. Manuf. Syst. 2019, 50, 9-24. [CrossRef]

121. Hajiagha, S.H.R.; Hashemi, S.S.; Mohammadi, Y.; Zavadskas, K.; Zavadskas, E.K. Fuzzy Belief Structure Based Vikor Method: An Application for Ranking Delay Causes of Tehran Metro System by Fmea Criteria. Transportation 2016, 31, 108-118. [CrossRef]

122. Jakimavičius, M.; Burinskienè, M. Multiple criteria assessment of a new tram line development scenario in Vilnius City public transport system. Transportation 2013, 28, 431-437. [CrossRef]

123. Shyur, H.-J.; Shih, H.-S. A hybrid MCDM model for strategic vendor selection. Math. Comput. Model. 2006, 44, 749-761. [CrossRef]

124. Ignaccolo, M.; Inturri, G.; Giuffrida, N.; Le Pira, M.; Torrisi, V. Public Engagement for Designing New Transport Services: Investigating Citizen Preferences from a Multiple Criteria Perspective. Transp. Res. Proc. 2019, 37, 91-98. [CrossRef]

125. Wann-Ming, W.; Jhong-You, H. Urban sustainable transportation planning strategies for livable City's quality of life. Habitat Int. 2018, 82, 9-27.

126. Piantanakulchai, M.; Saengkhao, N. Evaluation of alternatives in transportation planning using multi-stakeholders multi-objectives AHP modelling. In Proceedings of the Eastern Asia Society for transportation studies; 2003; Volume 4, pp. 1613-1628.

127. Nosal, K.; Solecka, K. Application of AHP Method for Multi-criteria Evaluation of Variants of the Integration of Urban Public Transport. Transp. Res. Proc. 2014, 3, 269-278. [CrossRef]

128. Awasthi, A.; Omrani, H.; Gerber, P. Investigating ideal-solution based multicriteria decision making techniques for sustainability evaluation of urban mobility projects. Transp. Res. Part A: Policy Pract. 2018, 116, 247-259. [CrossRef]

129. Yang, C.-H.; Lee, K.-C.; Chen, H.-C. Incorporating carbon footprint with activity-based costing constraints into sustainable public transport infrastructure project decisions. J. Clean. Prod. 2016, 133, 1154-1166. [CrossRef]

130. Hamurcu, M.; Alakaş, H.M.; Eren, T. Selection of rail system projects with analytic hierarchy process and goal programming. Sigma J. Eng. Nat. Sci. 2017, 8, 291-302.

131. Hamurcu, M.; Eren, T. Raylı sistem projeleri kararında AHS-HP ve AAS-HP kombinasyonu. Gazi Mühendislik Bilimleri Dergisi (GMBD) 2017, 3, 1-13.

132. Hamurcu, M.; Eren, T. An Application of Multicriteria Decision-making for the Evaluation of Alternative Monorail Routes. Mathematics 2018, 7, 16. [CrossRef]

133. Kirikkale. Available online: www.kirikkale.gov.tr/sehrimiz (accessed on 5 April 2020).

134. Doğan, B.; ve Kablan, A. Kırıkkale Şehir İçi Ulaşımda Alternatif Sistem Değerlendirmesi. Düzce Üniversitesi Bilim ve Teknoloji Dergisi 2016, 4, 431-437.

135. Arikan, Y.; Akkaş, Ö.P.; Çam, E.K. Kırıkkale İli Hafif Raylı Sistem Etüdünün Gerçekleştirilmesi. Uluslararası Muhendislik Arastirma ve Gelistirme Derg. 2018, 10, 6-11. [CrossRef]

136. Jeon, C.M.; Amekudzi, A.A.; Guensler, R.L. Evaluating Plan Alternatives for Transportation System Sustainability: Atlanta Metropolitan Region. Int. J. Sustain. Transp. 2010, 4, 227-247. [CrossRef] 
137. Litman, T. Sustainable transportation indicators-A recommended research program for developing sustainable transportation indicators and data. In Proceedings of the 2009 Transportation Research Board Annual Conference, CD-ROM, Washington, DC, USA, 11-15 January 2009.

138. Meyer, M.D.; Miller, E.J. Urban Transportation Planning; McGraw Hill: New York, NY, USA, 2001.

139. Nathanail, E. Measuring the quality of service for passengers on the hellenic railways. Transp. Res. Part A Policy Pract. 2008, 42, 48-66. [CrossRef]

140. Richardson, B.C. Sustainable transport: Analysis frameworks. J. Transp. Geogr. 2005, 13, 29-39. [CrossRef]

141. Sayers, T.; Jessop, A.; Hills, P. Multi-criteria evaluation of transport options-Flexible, transparent and user-friendly? Transp. Policy 2003, 10, 95-105. [CrossRef]

(C) 2020 by the authors. Licensee MDPI, Basel, Switzerland. This article is an open access article distributed under the terms and conditions of the Creative Commons Attribution (CC BY) license (http://creativecommons.org/licenses/by/4.0/). 